
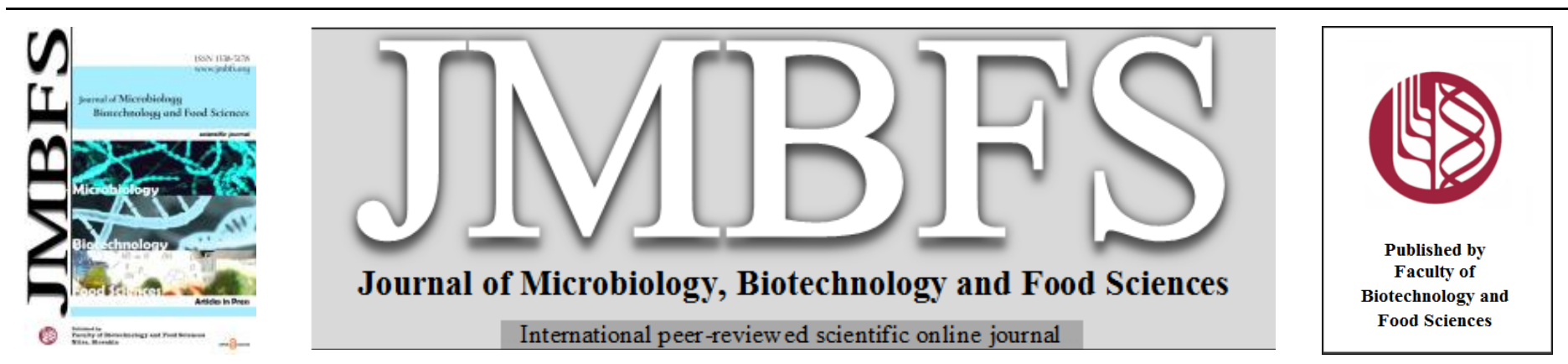

\title{
IDENTIFICATION OF VIRULENCE FACTORS AMONG ESBL-PRODUCING ESCHERICHIA COLI CLINICAL ISOLATES FROM GAZA STRIP, PALESTINE
}

\section{Ghassan TAYH ${ }^{1 *}$, Daram NAGARJUNA ${ }^{2}$, Rym BEN SALLEM ${ }^{1}$, Vivek VERMA ${ }^{2}$, Houssem BEN YAHIA ${ }^{1}$, Haythem GHARSA ${ }^{1}$, Manisha YADAV $V^{2}$ Karim BEN SLAMA ${ }^{1,3}$}

$\operatorname{Address}(e s)$ :

${ }^{1}$ Laboratoire des Microorganismes et Biomolécules Actives, Faculté des Sciences de Tunis, Université Tunis-El Manar, 2092 Tunis, Tunisie.

${ }^{2}$ Dr. B. R. Ambedkar Centre for Biomedical Research (ACBR), University of Delhi, Delhi-110007, India.

${ }^{3}$ Institut Supérieur des Sciences Biologiques Appliquées de Tunis, Université de Tunis El Manar, 9, Avenue Zouheir Essefi - 1006 Tunis, Tunisie.

*Corresponding author: ghassan.tayh@fst.rnu.tn ghassan.tayh@gmail.com

https://doi.org/10.15414/jmbfs.2865

\section{ARTICLE INFO}

Received 1. 4. 2020

Revised 30. 6. 2021

Accepted 12. 7. 2021

Published 1. 12. 2021

Regular article open $\odot$ access

\begin{abstract}
This study was done to assess the occurrence of virulence factors and correlation of phylogenetic grouping in ESBLs producing E. coli isolates from Palestine.

Twenty-seven ESBLs producing E. coli isolates were collected between April and June 2013 from three hospitals in Gaza. Detection of genes encoding virulence factors, pathogenicity associated island marker (PAI) and phylogenetic groups were studied by PCR. The correlation of $E$. coli phylogenetic grouping with the virulence factors in the isolates was studied. The clonal relationships between the isolates were tested by pulsed-field gel electrophoresis (PFGE).

Overall, $44.4 \%$ of the $27 \mathrm{E}$. coli isolates belonged to phylogroup B2, $44.4 \%$ to D and $11.2 \%$ to A. Among the isolates, fimH, traT and fimA were the most frequent virulence genes and were found over $85 \%$ of the isolates. PAIs was found in 8 isolates while the $t c p C$ gene was detected in one isolate. The overall prevalence of $P A I$ was higher in group B2 as compared to groups A and D (p<0.043). A clonal diversity was confirmed among our isolates (27 unrelated PFGE profiles). We report for the first time the prevalence of $t c p C$ as a new virulence marker and $P A I$ in clinical ESBLs-producing E. coli in Palestine.

This study indicates that most of the ESBL- positive isolates showed virulence genes and most strains belonged to phylogenetic groups B2 and D. The study suggested that high number of virulence genes in studied strains may be important factors in the infections development.
\end{abstract}

Keywords: virulence factors; phylogenetic groups; pathogenicity islands PAIs; ESBL producers; antibiotic resistance; E. coli

\section{INTRODUCTION}

Escherichia coli are common inhabitant microorganism of the human intestinal and various animals. However, some E. coli strains can cause urinary tract and blood-stream infections (Pitout, 2010)' (Manges, 2016). Extended-spectrum $\beta$ lactamases (ESBLs) are enzymes produced by Gram-negative bacteria, confer and increased resistance to $\beta$-lactam antibiotics such as ceftazidime, cefotaxime and aztreonam (Paterson and Bonomo, 2005). The overall data on ESBLcontaining E. coli in many countries of Middle East are worrying and this area may be one of the considerable epicenters of the ESBL pandemic globally (Tayh et al., 2016a).

The E. coli capacity enhances by many virulence factors (VFs) to cause infections; extraintestinal E. coli strains (ExPEC) carry genes encoding various VFs that can affect processes of host cell such as host defense avoidance mechanisms (capsule or O-specific antigen), combinations of adhesins ( $\mathrm{S}$ and $\mathrm{P}$ fimbriae), toxins (cytonecrotizing and hemolysin factor), and iron acquisition systems (yersiniabactin and aerobactin) (Ananias and Yano, 2008).VFs are important factors in the infections development by different mechanisms such as; help bacteria to attach and invade host cells, lyses host cells via toxins, evade host defenses and sequestering iron from the host which important for bacterial cellular activities. Genes coding for VFs are located with each other on large chromosomal regions recognized as pathogenicity islands (PAIs) (Bingen-Bidois et al., 2002).

Extraintestinal pathogenic E. coli differ with commensal according to phylogenetic attributes and virulence determinants (Johnson and Stell, 2000). Recently, studies indicate that the commensal strains belong to phylogenetic groups B1 and A. However, ExPEC belong particularly to group B2 and, to a lower extent, phylogenetic group D (Zhang et al., 2002) (Duriez et al., 2001).

Toll/interleukin-1 (IL-1) receptor (TIR) domain plays an important role in the mammalian to activate innate immunity. Pathogenic microorganisms improved mechanisms to inactivation the TLR dependent host defense and to raise the bacterial virulence for a host (Nagarjuna et al., 2015a). Recently, the TIR homologous protein TcpC has been detected in E. coli strains acts as a virulence factor by inhibiting innate host responses, enhancing persistence of bacteria and increase infection severity. In a previous study, they confirmed a role of $t c p C$ in the urinary tract infection pathogenesis in $E$. colibut its role in sepsis pathogenesis is unknown (Cirl et al., 2008). In other bacteria, TIR domain contain protein $(B t p B)$ is recognized as a virulence factor that control of local inflammatory responses in the enhancement of chronic brucellosis (Salcedo et al., 2013). SaTlp1 and SaTlp2 are virulence factor of Staphylococcus aureus that interact in mammalian cells with the innate immune signaling (Spear et al., 2012).

The virulence factors in ESBL-positive E. coli isolates were studied from different cases in different countries, from healthy school children in India (Zhang et al., 2002), from long-term hospitalized patients in China (Zhao et al., 2015) and diarrheic cattle in France (Wayne, 2014).

The objective of this work was to investigate phylogenetic group and major VFs among ESBLs producing E. coli isolates from Palestinian hospitals in Gaza Strip. This study is the first investigation of the prevalence of virulence factors, $P A I$ and $t c p C$ among ESBLs producing $E$. coli isolates and of the association of virulence factors with the phylogenetic group in ESBLs producing $E$. coli isolates in Palestine.

\section{MATERIAL AND METHODS}

\section{Isolation and identification}

The samples were obtained from patients visiting Palestinian hospitals in Gaza Strip and were transferred to the laboratory for processing. The isolated bacteria were cultured on plates of blood agar and MacConkey agar. Among the clinical isolates were obtained from urinary tract infection and wound infection, 69 were identified as $E$. coli by standard biochemical tests. These isolates were confirmed 
by a species PCR of the uidA gene which encoding the $\beta$-glucuronidase (Jouini et al., 2010). E. coli strains were stored in $30 \%$ glycerol at $-80{ }^{\circ} \mathrm{C}$ for further use.

\section{Antibiotic susceptibility testing}

Susceptibility testing was performed according to CLSI by the disc diffusion method for the following antimicrobial agents: amoxicillin-clavulanic acid, ampicillin, ceftazidime, cefoxitin, gentamicin, cefotaxime, amikacin, nalidixic acid, tobramycin, ciprofloxacin, kanamycin, imipenem, tetracycline, trimethoprim-sulfamethoxazole, and chloramphenicol (Bio-Rad, France) (Wayne, 2014). The E. coli isolates were examined for ESBL production by double-disk synergy method by using a disk of amoxicillin/ clavulanic acid with two antimicrobial disks (ceftazidime and cefotaxime) (Kaur et al., 2013), the ESBL producing isolates were selected for more examinations. E. coli ATCC 25922 was used as a control strain.

\section{Isolation of genomic DNA and PCR amplification}

All isolates of $E$. coli confirmed by biochemical and molecular tests were subcultured on tryptone soy broth at $37^{\circ} \mathrm{C}$ for $18 \mathrm{~h}$. The extraction of the DNA was performed by the standard sodium acetate precipitation method. The concentration and the purity of DNA were determined using a NanoDrop ${ }^{\mathrm{TM}}$ spectrophotometer at A260/280 nm

PCR amplification was performed in $25 \mu \mathrm{L}$ reaction volume containing $2 \mu \mathrm{L}$ DNA template, $1 \times$ buffer, $1.5 \mathrm{mM} \mathrm{MgCl} 2,0.4 \mathrm{mM}$ dNTPs, $0.6 \mu \mathrm{M}$ forward and reverse primers and $1 \mathrm{U}$ Taq DNA polymerase (Biomer). PCR was done with a DNA thermal cycle (applied biosystems thermal cycler). The PCR reaction condition was as follows: initial denaturation at $94{ }^{\circ} \mathrm{C}$ for $4 \mathrm{~min}$; 30 cycles of denaturation at $94{ }^{\circ} \mathrm{C}$ for $45 \mathrm{sec}$, annealing for $45 \mathrm{sec}$ at specific temperature (Table 1), extension at $72^{\circ} \mathrm{C}$ for $45 \mathrm{sec}$; and a final extension $\left(72{ }^{\circ} \mathrm{C}, 10 \mathrm{~min}\right)$.

\section{Phylogenetic determination in ESBL-producing E. coli}

PCR amplification was used to detect the presence of two genes (chuA, yjaA) and a fragment of DNA known as TspE4C2 to detect phylogenetic grouping (A, B1, B2 and D) of E.coli isolates. Primers sequences are given in Table 1. The interpretation of results was done by dichotomous decision tree (Zhang $\boldsymbol{e t}$ al., 2002)

\section{Detection of Virulence factors}

The $E$. coli pathogenicity is correlating with the VFs that may be encoded by chromosomal and plasmid genes, and in this study 13 genes encoding VFs were studied. The selected genes were aer (aerobactin iron uptake system), cnfl (cytotoxic necrotizing factor), $b f p$ (bundle-forming pilus), fimA (encoding type 1 fimbriae), hlyA (haemolysin), stx (shiga toxin), papC (P fimbriae), papG allele III (adhesion PapG class III), eae (enteropathogenic attachment and effacement), sfa (S fimbriae), afa (A fimbriae), traT (serum resistance), fimH (encoding type 1 fimbriae), pathogenicity associated island marker (PAI) and the tcpC gene encoding VFs often found in pathogenic $E$. coli strains, were tested in the ESBLpositive isolates by PCR using specific primers (Table 1) (Slama et al., 2011).

The PCR was performed in our study including in all cases control positive and negative from the Ambedkar Centre for Biomedical Research (ACBR) and Universite' Tunis-El Manar collection.

Table 1 Primers and polymerase chain reaction assay for virulence factors and phylogenetic genes

\begin{tabular}{|c|c|c|c|c|c|}
\hline Functional category & Gene & Primer sequence (5'-3') & $\begin{array}{c}\text { Size of } \\
\text { amplicon } \\
\text { (bp) }\end{array}$ & $\begin{array}{c}\text { Annealing } \\
\text { temperature } \\
\left({ }^{\circ} \mathrm{C}\right) \\
\end{array}$ & Reference \\
\hline \multicolumn{6}{|c|}{ Phylogenetic genes } \\
\hline & chuA & $\begin{array}{l}\text { F: GACGAACCAACGGTCAGGAT } \\
\text { R: TGCCGCCAGTACCAAAGACA }\end{array}$ & 279 & 55 & (Slama et al., 2011) \\
\hline & yjaA & $\begin{array}{l}\text { F: TGAAGTGTCAGGAGACGCTG } \\
\text { R: ATGGAGAATGCGTTCCTCAAC }\end{array}$ & 211 & 55 & (Slama et al., 2011) \\
\hline & $T s p E 4 C 2$ & $\begin{array}{l}\text { F: GAGTAATGTCGGGGCATTCA } \\
\text { R: CGCGCCAACAAAGTATTACG }\end{array}$ & 152 & 55 & (Slama et al., 2011) \\
\hline \multicolumn{6}{|c|}{ Virulence factors } \\
\hline \multicolumn{6}{|c|}{ Toxins } \\
\hline Haemolysin & Hly & $\begin{array}{l}\text { F: AACAAGGATAAGCACTGTTCTGGCT } \\
\text { R : ACCATATAAGCGGTCATTCCCGTCA }\end{array}$ & $1177 \mathrm{pb}$ & 63 & (Ruiz et al., 2002) \\
\hline cytotoxic necrotizing factor & cnfl & $\begin{array}{l}\mathrm{F}: \text { :AAGATGGAGTTTCCTATGCAGGAG } \\
\mathrm{R}: \text { CATTCAGAGTCCTGCCCTCATTATT }\end{array}$ & $498 \mathrm{pb}$ & 63 & (Ruiz et al., 2002) \\
\hline Shiga toxin & Stx & $\begin{array}{l}\text { F: CTTCGGTATCCTATTCCCGG } \\
\text { R: GGATGCATCTCTGGTCATTG }\end{array}$ & $484 \mathrm{pb}$ & 63 & $\begin{array}{l}\text { (Tahamtan et al., } \\
\text { 2010) }\end{array}$ \\
\hline \multicolumn{6}{|c|}{$\begin{array}{c}\text { Adhesins } \\
\end{array}$} \\
\hline P fimbriae & papC & $\begin{array}{l}\text { F: GACGGCTGTACTGCAGGGTGTGGCG } \\
\text { R : ATATCCTTTCTGCAGGGATGCAATA }\end{array}$ & $328 \mathrm{pb}$ & 63 & (Ruiz et al., 2002) \\
\hline Bundle-forming pilus & $B f p$ & $\begin{array}{l}\mathrm{F}: \text { ACAAAGATACAACAAACAAAAA } \\
\mathrm{R}: \text { TTCAGCAGGAGTAAAAGCAGTC }\end{array}$ & $260 \mathrm{pb}$ & 63 & (Ruiz et al., 2002) \\
\hline P-fimbrialadhesin III & papGIII & $\begin{array}{c}\text { F : CATTTATCGTCCTCCTCAACTTAG } \\
\text { R : AAGAAGGGATTTTGTAGCGTC }\end{array}$ & $482 \mathrm{pb}$ & 55 & (Ruiz et al., 2002) \\
\hline encoding type 1 fimbriae & fim $A$ & $\begin{array}{l}\text { F : GTTGTTCTGTCGGCTCTGTC } \\
\text { R : ATGGTGTTGGTTCCGTTATTC }\end{array}$ & $447 \mathrm{pb}$ & 55 & (Ruiz et al., 2002) \\
\hline $\begin{array}{l}\text { Enteropathogenic attachment } \\
\text { and effacement }\end{array}$ & Eae & $\begin{array}{c}\mathrm{F}: \text { CATTATGGAACGGCAGGT } \\
\mathrm{R}: \text { ATCTTCTGCGTACTGCGTTCA }\end{array}$ & $760 \mathrm{pb}$ & 55 & (Jouini et al., 2010) \\
\hline encoding type 1 fimbriae & fimH & $\begin{array}{l}\text { F TGCAGAACGGATAAGCCGTGG } \\
\text { R GCAGTCACCTGCCCTCCGGTA }\end{array}$ & 506 & 55 & $\begin{array}{l}\text { (Johnson and Stell, } \\
\text { 2000) }\end{array}$ \\
\hline S fimbriae & $S f a$ & $\begin{array}{l}\text { F CTCCGGAGAACTGGGTGCATCTTAC } \\
\text { R CGGAGGAGTAATTACAAACCTGGCA }\end{array}$ & 408 & 54 & $\begin{array}{l}\text { (Birosova et al. } \\
\text { 2004) }\end{array}$ \\
\hline A fimbriae & $A f a$ & $\begin{array}{l}\text { F GCTGGGCAGCAAACTGATAACTCTC } \\
\text { R CATCAAGCTGTTTGTTCGTCCGCCG }\end{array}$ & 793 & 60 & $\begin{array}{c}\text { (Birosova } \text { et al. } \\
\text { 2004) }\end{array}$ \\
\hline \multicolumn{6}{|c|}{ Invasion } \\
\hline aerobactin iron uptake system & Aer & $\begin{array}{l}\text { F: TACCGGATTGTCATATGCAGACCGT } \\
\text { R : AATATCTTCCTCCAGTCCGGAGAAG }\end{array}$ & $602 \mathrm{pb}$ & 63 & (Ruiz et al., 2002) \\
\hline Serum resistance & traT & $\begin{array}{l}\text { F GGTGTGGTGCGATGAGCACAG } \\
\text { R CACGGTTCAGCCATCCCTGAG }\end{array}$ & 288 & 57 & $\begin{array}{c}\text { (Johnson and Stell, } \\
\text { 2000) }\end{array}$ \\
\hline \multicolumn{6}{|c|}{ Others } \\
\hline $\begin{array}{l}\text { TIR domain-containing protein } \\
(t c p C)\end{array}$ & tcpC & $\begin{array}{c}\text { F GAGTGGAAGGAGGTTGAGGC- } \\
\text { R GCAGTGCCATTTTATCCGCC }\end{array}$ & 544 & 55 & (Erjavec et al., 2010) \\
\hline Pathogenicity associated island & PAI & $\begin{array}{l}\text { F GGACATCCTGTTACAGCGCGCA } \\
\text { R TCGCCACCAATCACAGCCGAAC }\end{array}$ & 922 & 57 & $\begin{array}{c}\text { (Johnson and Stell, } \\
\text { 2000) }\end{array}$ \\
\hline
\end{tabular}




\section{Data analysis}

The data of phylogenetic grouping and VFs in ESBLs producing E. coli isolates were analyzed by the Statistical Package for the Social Sciences (SPSS) version 17 software (IBM Corporation, Somers, NY). Data comparison was achieved via analysis of Pearson's Chi-square. The level of statistical significance was set at $\mathrm{P}<0.05$.

\section{Pulsed-field gel electrophoresis (PFGE) analysis}

Genomic relatedness of the 27 ESBLs positive $E$. coli isolates was determined by PFGE using a restriction enzyme Xbal. The resulting restriction patterns of genomic DNA were analyzed with visual method and by GelCompar II software using the UPGMA algorithm and the Dice similarity coefficients (Slama et al., 2011)

\section{RESULTS}

In this study we screened 27 ESBL-containing strains from urine $(n=19)$ and wound swabs $(n=8)$ from three Palestinian hospitals for the determination of phylogenetic groups, and important VFs associated sequences responsible for extraintestinal pathogenesis.

\begin{tabular}{|c|c|c|c|c|c|c|c|c|c|c|c|c|}
\hline Result code & fimH & sfa & $a f a$ & $\operatorname{traT}$ & tcpC & PAI & $\operatorname{fim} A$ & pap $C$ & papG III & aer & Phylogenetic groups & Specimen \\
\hline Ec414 & $+*$ & $-*$ & - & + & - & - & + & - & - & - & A & Urine \\
\hline Ec515 & + & - & + & + & - & - & + & - & - & - & $\mathrm{D}$ & Wound \\
\hline Ec621 & + & - & - & + & - & - & + & - & - & - & $\mathrm{D}$ & Wound \\
\hline Ec740 & + & - & - & + & - & - & + & - & - & - & $\mathrm{B} 2$ & Urine \\
\hline Ec855 & + & - & - & + & - & + & + & - & - & - & B2 & Urine \\
\hline Ec956 & + & - & - & + & - & + & + & - & - & - & B2 & Wound \\
\hline Ec058 & + & - & - & + & - & + & + & + & - & - & $\mathrm{B} 2$ & Urine \\
\hline Ec168 & + & - & - & + & - & + & - & + & - & - & B2 & Urine \\
\hline Ec271 & + & - & - & + & - & + & - & + & - & - & $\mathrm{D}$ & Urine \\
\hline Ec375 & + & - & - & + & - & - & + & - & - & - & $\mathrm{D}$ & Urine \\
\hline Ec476 & + & - & - & + & - & - & + & - & - & - & A & Wound \\
\hline Ec579 & + & + & - & + & - & - & - & - & + & - & $\mathrm{D}$ & Wound \\
\hline Ec683 & + & + & - & + & - & + & + & - & - & - & A & Wound \\
\hline Ec892 & + & + & - & + & + & + & + & - & - & - & B2 & Urine \\
\hline Ec998 & + & + & - & + & - & + & + & + & - & + & $\mathrm{D}$ & Urine \\
\hline $\mathrm{Ec} 0108$ & + & + & + & + & - & - & + & - & - & - & $\mathrm{D}$ & Urine \\
\hline Ec1116 & + & - & + & + & - & - & + & - & - & - & $\mathrm{D}$ & Urine \\
\hline Ec2117 & + & + & - & + & - & - & + & - & - & - & $\mathrm{D}$ & Urine \\
\hline Ec3121 & + & - & + & + & - & - & + & - & - & - & $\mathrm{D}$ & Urine \\
\hline Ec4126 & + & + & + & + & - & + & + & - & - & + & B2 & Urine \\
\hline Ec5134 & + & + & + & + & - & - & + & - & - & - & $\mathrm{D}$ & Urine \\
\hline Ec6138 & + & - & - & + & - & - & + & + & - & + & B2 & Urine \\
\hline Ec7141 & + & - & + & + & - & - & + & + & - & + & $\mathrm{D}$ & Wound \\
\hline Ec8142 & + & + & - & + & - & - & + & + & - & + & B2 & Wound \\
\hline Ec147 & - & - & - & - & - & - & + & - & - & + & B2 & Urine \\
\hline Ec9151 & + & - & + & + & - & + & - & - & - & + & B2 & Urine \\
\hline
\end{tabular}

\section{Antibiotic resistance among the isolates}

All 27 E. coli isolates were tested to antimicrobial susceptibility against fifteen antibiotics. The percentage of resistance to antibiotics among ESBL positive isolates is shown in Figure 1. All isolates were resistance to cefotaxime and ampicillin. Resistant to sulfamethoxazole/trimethoprim, tetracycline, nalidixic acid, ciprofloxacin, ceftazidime and kanamycin were $77.8 \%, 74.1 \%, 66.7 \%$, $59.3 \%, 51.9 \%$ and $51.9 \%$ respectively. Imipenem, amikacin and gentamicin were the most effective antibiotics with the studied isolates, where $85.2 \%, 81.5 \%$ and $74.1 \%$ were susceptible to imipenem, amikacin and gentamycin respectively. Sensitivity to amoxicillin-clavulanic acid, cefoxitin, tobramycin and chloramphenicol among ESBL producers were $74.1 \%, 74.1 \%, 63 \%$ and $63 \%$ respectively. Most of the isolates were found to be insensitivity to at least one agent in three or more antimicrobial classes, so they are considered as multidrugresistant (MDR).

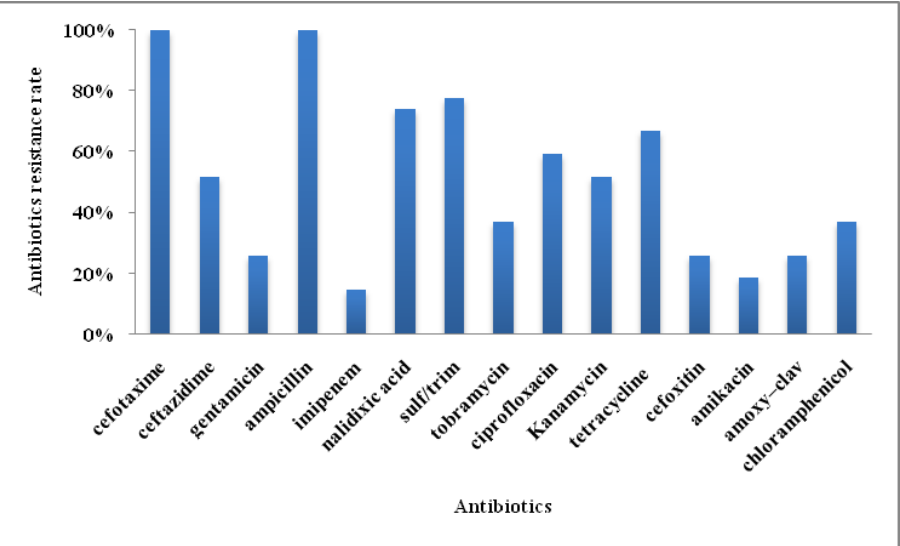

Figure 1 Antibiotics resistance of 27 ESBL-positive $E$. coli isolates

\section{Phylogenetic groups and clonal relationship of isolates}

The analysis of phylogenetic grouping was classified into four groups (A, B1, $\mathrm{B} 2$, and D). Our study observed that ESBLs positive E. coli isolates belonged to the phylogroups $\mathrm{B} 2(\mathrm{~N}=12 ; 44.4 \%), \mathrm{D}(\mathrm{N}=12 ; 44.4 \%)$, and $\mathrm{A}(\mathrm{N}=3 ; 11 \%)$ whereas none of the isolates belonged to phylogroup B1. The PFGE analysis of the E. coli isolates demonstrated a wide genetic diversity. 


\section{Virulence profile}

In this study, genes related to adhesins (fimA, fimH, sfa, afa, papC, papGIII, bfp, eae), toxins ( $h l y, c n f l)$, invasion (aer) and protectins, like serum resistance (traT) and others $(P A I$ and $t c p C)$ were investigated. The prevalence of the virulence factors are reported in Table 2 and Figure 2. In regard to adhesins, the fimH was the most frequent virulence gene and was found in $96.3 \%(26 / 27)$ of the ESBLs producing $E$. coli isolates followed by fimA $85.2 \%$ (23/27). The frequency of $s f a$ gene, afa, papC, and papGIII among the isolates was $33.3 \%, 29.6 \%, 25.9 \%$ and $7.4 \%$ respectively. TraT was detected in most of the isolates $96.3 \%(26 / 27)$ However, aer was found in $29.6 \%$ of the isolates. None of the isolates harbored cnfl, hlyA, eae, bfp, or stx. $40.7 \%$ of the isolates carried PAI associated sequence $(11 / 27)$, while $t c p C$ gene was detected only in one isolate $(3.7 \%)$.

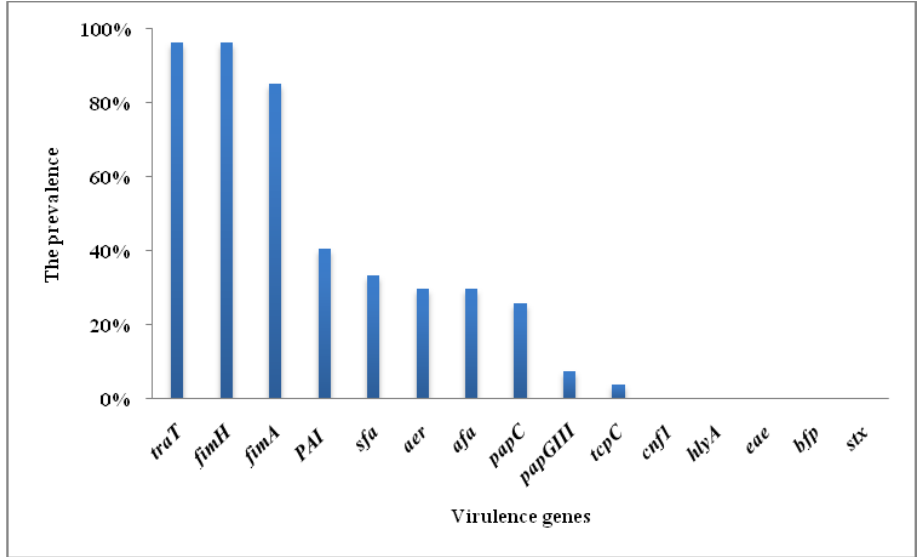

\section{Correlation of phylogroups with VFs in ESBLs producing $E$. coll}

The correlation of phylogenetic grouping with the virulence factors in different infections has been previously reported. The frequency of the virulence genes (fimA, papG III, cnfl, hlyA, aer, papC, sfa, afa,traT, fimH, eae, and bfp, tcpC and $P A I)$ in the phylogenetic groups (A, B1, B2 and D) was studied. The prevalence of $P A I$ in our isolates was higher in group $\mathrm{B} 2$ compared to $\mathrm{A}$ and $\mathrm{D}$ groups ( $\mathrm{p}<0.043$ ). However, no clear difference in the prevalence of afa, fimH, sfa, traT and $t c p C$ in the $E$. coli isolates among various phylogenetic groups was seen. $T c p C$ was found in one $E$. coli isolate and was restricted to phylogenetic group $\mathrm{B} 2$ (Figure 3). afa was found to be prevalent more in group $\mathrm{D}(\mathrm{N}=6)$ than the group B2 $(\mathrm{N}=2)$. However, aer was found positive in 6 isolates for group B2 whereas 2 belong to group D (table 3 and figure 3 ).

Table 3 The frequency of the virulence genes in the phylogenetic groups

\begin{tabular}{|c|c|c|c|c|c|}
\hline \multirow{2}{*}{$\begin{array}{l}\text { virulence } \\
\text { genes }\end{array}$} & \multicolumn{4}{|c|}{ Phylogenetic grouping $(n=27) \%$} & \multirow{2}{*}{$P$-value } \\
\hline & $\mathbf{A}(\%)$ & B2 (\%) & D (\%) & Total & \\
\hline$P A I$ & $1(3.7 \%)$ & $8(29.6 \%)$ & $2(7.4 \%)$ & $\begin{array}{c}11 \\
(40.7 \%)\end{array}$ & 0.043 \\
\hline FimH & $3(11.1 \%)$ & $\begin{array}{c}11 \\
(40.7 \%)\end{array}$ & $\begin{array}{c}12 \\
(44.4 \%)\end{array}$ & $\begin{array}{c}26 \\
(96.3 \%)\end{array}$ & 0.523 \\
\hline$S f a$ & 0 & $4(14.8 \%)$ & $5(18.5 \%)$ & $9(33.3 \%)$ & 0.392 \\
\hline Afa & 0 & $2(7.4 \%)$ & $6(22.2 \%)$ & $8(29.6 \%)$ & 0.099 \\
\hline $\operatorname{TraT}$ & $3(11.1 \%)$ & $\begin{array}{c}11 \\
(40.7 \%)\end{array}$ & $\begin{array}{c}12 \\
(44.4 \%)\end{array}$ & $\begin{array}{c}26 \\
(96.3 \%)\end{array}$ & 0.523 \\
\hline TcpC & 0 & $1(3.7 \%)$ & 0 & $1(3.7 \%)$ & 0.523 \\
\hline FimA & 3 & $10(37 \%)$ & $10(37 \%)$ & $\begin{array}{c}23 \\
(85.2 \%)\end{array}$ & 0.746 \\
\hline PapC & 0 & $4(14.8 \%)$ & $3(11.1 \%)$ & $7(25.9 \%)$ & 0.497 \\
\hline Aer & 0 & $5(18.5 \%)$ & $2(7.4 \%)$ & $7(25.9 \%)$ & 0.209 \\
\hline
\end{tabular}

Figure 2 The prevalence of virulence factors among $E$. coli isolates
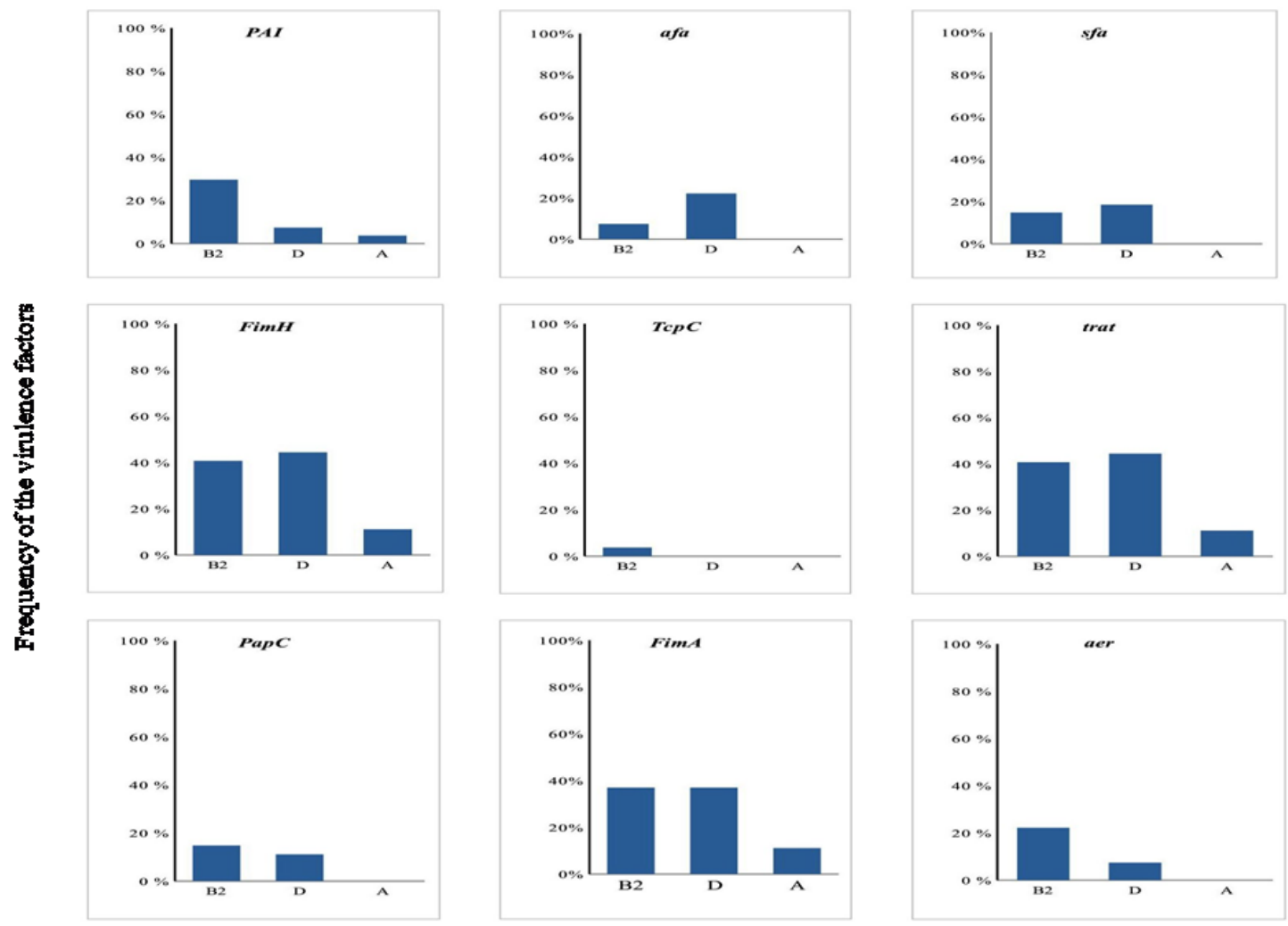

Phylogenetic grouping

Figure 3 The prevalence of virulence factors among phylogenetic groups of E. coli isolates

\section{DISCUSSION}

E. coli is a normal microorganism inhabitant of the human intestines and can also cause severe human infections as an opportunistic pathogen. It is the most common Gram-negative bacillus causing infections in the urinary tract and blood-stream (Pitout, 2010). ESBL-positive E. coli strains are a major worry problem in many hospitals worldwide, being implicated in many human sporadic infections and causing outbreaks (Carattoli et al., 2008).

Extraintestinal E. coli strains owing to a range of virulence factors, such as adhesins, hemolysin and fimbriae, which affect of host cell processes and contribute to bacterial pathogenesis (Ananias and Yano, 2008). The genes encoding virulence factors are usually carried on pathogenicity islands, which have been studied in $E$. coli isolates previously. The pathogenicity of $E$ coli strains enhanced by several virulence factors (Schmidt and Hensel, 2004). They are the products of different genes, which can be detected by the PCR method. In this study, we have studies the antibiotics resistance, phylogenetic grouping and VFs, in 27 ESBL containing E. coli isolated from urine and wound swabs from three Palestinian hospitals. The relationship between the presence of VFs and the phylogenetic groups was also analyzed.

The ESBL-containing E. coli isolates show co-resistance to many categories of commonly used antibiotics causing in limitation associated with therapeutic (antibiotics) options. Whereas imipenem was the most effective antibiotics with 
the studied isolates. Similar reports of gram-negative bacteria were reported from burn units in Palestine (Elmanama et al., 2013; Tayh et al., 2016b). The antibiotics resistance results are very significant for the physicians to choose an appropriate antimicrobial treatment. The higher proportion of resistance and ESBL rate in our study may be a result of the availability of antibiotics without a prescription. Reduction of antibiotic resistance can be by using antibiotics according antimicrobial stewardship guidelines, performing diagnostic testing and antimicrobial susceptibility testing, as well as via developments of new antibiotic (Lee et al., 2013).

Extraintestinal E. coli which cause infections have been shown to belong to phylogroups D and B2 (Smith et al., 2007). The results of this study indicated that most isolates belonged to phylogroups B2 $(44.4 \%)$ and D $(44.4 \%)$ which is in agreement with previous findings (Slama et al., 2011). Group A was the least frequently isolated phylogenetic group among our isolates, which is in accordance with similar studies (Girardini et al., 2012).

In a recent study in the West Bank, forty-one E. coli isolates were obtained from UTI hospitalized patients in three Palestinian hospitals and the results revealed that 13 isolates belonged to phylogroup B2, 12 isolates to group D, 11 isolates to $A$ and five isolates to B1 (Adwan et al., 2014). In a Turkish study, ESBLpositive E. coli were distributed in groups D $(35 \%)$, A $(35 \%)$ and B2 $(30 \%)$ (Yumuk et al., 2008). In the Canadian study, it was detected that the majority of ESBL-producing isolates were belonged to group D (63\%), while $21 \%$ of isolates were derived from A and 13\% from group B2 (Pitout et al., 2005).

$\mathrm{PAI}$ is highly prevalent among $E$. coli isolates causing extraintestinal infections and mostly belonged to phylogenetic groups D and B2 (Östblom et al., 2011) Our study was proved the prevalence of eleven PAI in E coli strains isolated from the wound infection and urine with the high prevalence of PAI in group B2. Herzer et al. (Herzer $\boldsymbol{e t}$ al., 1990) reported that E. coli caused extraintestina infections were enriched by PAIs. In a recent study in Estonia, among 432 isolates of phenotypically ESBL producing $E$. coli the PAI was detected in 215 $(51 \%)$, this gene was identified to be more predominant in phylogenetic group B2 (186 isolates) (Lillo et al., 2014). Carattoli et al. found PAI in all ESBL containing $E$. coli isolates, and most of the isolates belonged to B2 phylogenetic group (Carattoli et al., 2008). In Brazil, 22 PAIs were found among E. coli strains and 15 of the total PAIs identified were present in group B2 (Koga $\boldsymbol{e t}$ al. 2014). Our study for the first time identifies PAIs in E. coli isolates that produce ESBL in Palestine.

The pathogenicity of $E$. coli is a complex multi-factorial mechanism consisting of numerousVFs which vary among the different pathotypes. These factors include invasions, attachment functions, modifying factors of the host cell surface, and other VFs and many different toxins that affect in the target host cells (Casadevall and Pirofski, 1999). The fimbriae factors allow E. coli to attach to the mucosa of the small gut where they can transfer their toxins straight to their target (Kuhnert et al., 2000). Genes coding for fimbrial Adhesins [fimA, fimH, $s f a$ and $a f a$ ] represent the most common virulence factors of our $E$. coli isolates. Our data showed the highest frequency of fimH and fimA (96.3\% and 85.2\%) compared with another fimbrial adensins genes, which may indicate an important role of the virulence genes in $E$. coli causing infection. The high prevalence of fim genes in our isolates is in accordance with other studies (Ruiz et al., 2002; Micenkova et al., 2014; Nagarjuna et al., 2015b). A study in Tunisia, among 18 ESBL positive E. coli isolates fimA was found in 11 isolates (Jouini et al., 2010). Concerning $\mathrm{P}$ fimbriae (papC), our findings are in agreement with the results of previous clinical studies, approximately $25-35 \%$ possess $\mathrm{P}$ fimbriae (Koga $\boldsymbol{e t}$ al., 2014). In contrast to a study in America, PapC was high prevalent $(77 \%)$ (Johnson and Stell, 2000). The detection of $\mathrm{P}$ fimbriae ( region of the Czech Republic was reported in 2014 in a study evaluating the presence of virulence factors among $1181 \mathrm{E}$. coli isolates of human fecal origin in which Pap was detected in $33.3 \%$ (201/603) of extraintestinal pathogenic E.coli and $10.6 \%(19 / 179)$ of Diarrhea-associated E. coli, whereas none of the commensal isolates harbored Pap (Micenkova et al., 2014).

The distribution of the $\mathrm{S}$ fimbriae encoding operons detected in E. coli isolates was also similar to previous data (Micenkova et al., 2014). In this study, we observed that $29.6 \%(\mathrm{n}=8)$ of the $E$. coli isolates were carrying afa (afimbrial adhesins). Tarchouna et al. found afa gene in $20 \%$ of $E$. coli isolates from urine (Tarchouna et al., 2013). Another work revealed that the afa gene was found in $2 \%$ of E. coli strains from urine samples (Birosova et al., 2004). In our study, afa was found to be more prevalent in group D than the group B2. Thus our results were in agreement with the previous published data (Johnson et al., 2005).

TraT gene which encodes an outer membrane lipoprotein that participate to serum resistance (Johnson and Russo, 2002) was identified in high frequency in $96.3 \%$ of the isolates. The high predominance of the traT studied in E. coli strains may be indicating its function in the development of infection. In India, the results obtained were similar to our findings; the prevalence of $t r a T$ in $E$. coli was $84.5 \%$ (Nagarjuna et al., 2015b). An American study, among 75 urosepsis isolates of E. coli, traT was found in $68 \%$ of the isolates (Johnson and Stell, 2000). The invasion factor encoded by the aer gene (Iron uptake) was demonstrated in $29.6 \%$ of $E$. coli isolates. The high effectiveness of iron uptake system is mediated by the siderophore aerobactin. The existence of a siderophore may be a significant factor in the infection development (Kuhnert et al., 2000) The frequency of aer gene was detected in $30 \%$ of the E. coli isolates causing cystitis in a Spinach study, and this is in agreement with our findings (Ruiz et al., 2002). However, in a study in France, aer gene was higher than that of our study (80\%) (Bingen-Bidois et al., 2002). In another study, that has been done in a Tunisian hospital, it was observed that aer gene was found in $85 \%$ of ESBLcontaining E. coli strains (Slama et al., 2011). In our isolates most of aer positive isolates belongs to group B2 and this is in agreement with previous study (Bingen-Bidois et al., 2002).

The $T c p C$ gene was detected in only one isolate. $T c p C$ was first detected by Cirl et al. and they found that $t c p C$ homologous sequences were confirmed in $40 \%$ and $21 \%$ of $E$. coli strains from pyelonephritis and cystitis respectively. Their findings proposed that $t c p C$ increases the severity of urinary tract infection in humans and they provided the first proof that E.coli can survive and spread in the host by interfering with TLR signaling (Cirl et $\boldsymbol{a l}$., 2008). The rate of $t c p C$ was lower among our isolates, in comparison with the finding of other studies; In Slovenia, they reported that they detected $t c p C$ in $49(23 \%)$ of the pathogenic $E$ coli isolates (Erjavec et al., 2010). In a recent study, they investigated the prevalence of the $t c p C$ gene in blood and fecal $E$. coli strains from India. They found the prevalence of $t c p C$ gene in the phylogenetic groups B2 and D was higher $(40.3 \%)$ than the B1 and A groups (9.6\%) (Nagarjuna et al., 2015a).

\section{CONCLUSION}

In conclusion, we investigated phylogenetic grouping and VFs profile in ESBLsproducing $E$. coli isolates from Palestine. To the best of our knowledge, this is the first report $t c p C$ as new virulence marker and PAI in clinical ESBLs-positive $E$. coli in Palestine. The results indicate that E. coli from phylogenetic groups B2 and $\mathrm{D}$ were predominate in our isolates. Most of the ESBL- positive E. coli strains showed virulence genes. FimH, $\operatorname{traT}$ and fimA were highly prevalent among the isolates. This study exhibited that a high number of virulence factors in $E$. coli strains may be significant factors in the development of infection. The isolates show resistance to many classes of commonly used antibiotics causing in limitation associated with therapeutic options. A good recognition of the virulence factors and antimicrobial susceptibility of clinical ESBL-positive $E$. coli can contribute in early diagnosis and treatment of these infections. The findings are important in choice the most effective antibiotic based on antibiogram and application of strategies of infection prevention and control.

\section{Declarations:}

Funding: This study was financed by the Tunisian Ministry of Higher Education, Scientific Research and Technology and partly supported by the Centre for Science \& Technology of Non-Aligned and Other Developing Countries, New Delhi, India (Ref. No. NAM-05/74/2015). GH. TAYH is the recipient of RTFDCS fellowship.

Competing Interests: The authors declare that they have no conflict of interest.

Ethical clearance: This research study was confirmed by the local Helsinki Committee in Gaza strip, an agreement was taken from patients to participate freely in this study.

\section{REFERENCES}

Adwan, K., Jarrar, N., Abu-Hijleh, A., Adwan, G. \& Awwad, E. (2014) Molecular characterization of Escherichia coli isolates from patients with urinary tract infections in Palestine. Journal of medical microbiology, 63(2), 229-234. http://doi.org/10.1099/jmm.0.067140-0

Ananias, M., \& Yano, T. (2008). Serogroups and virulence genotypes of Escherichia coli isolated from patients with sepsis. Brazilian Journal of Medical and Biological Research, 41(10), 877-883. http://doi.org/10.1590/S0100 $\underline{879 X 2008001000008}$

Bingen-Bidois, M., Clermont, O., Bonacorsi, S. p., Terki, M., Brahimi, N. m. Loukil, C., Barraud, D. \& Bingen, E. (2002). Phylogenetic analysis and prevalence of urosepsis strains of Escherichia coli bearing pathogenicity islandlike domains. Infection and immunity, 70(6), 3216-3226 http://doi.org/10.1128/IAI.70.6.3216-3226.2002

Birosova, E., Siegfried, L., Kmet'ova, M., Makara, A., Ostro, A., Gresova, A., Urdzik, P., Liptakova, A., Molokacova, M. \& Bartl, R. (2004). Detection of virulence factors in $\alpha$-?haemolytic Escherichia coli strains isolated from various clinical materials. Clinical microbiology and infection, 10(6), 569-573. http://doi.org/10.1111/j.1469-0691.2004.00922.x

Carattoli, A., Garcia-Fernandez, A., Varesi, P., Fortini, D., Gerardi, S., Penni, A., Mancini, C. \& Giordano, A. (2008). Molecular epidemiology of Escherichia coli producing extended-spectrum $\beta$-lactamases isolated in Rome, Italy. Journal of clinical microbiology, 46(1), 103-108. http://doi.org/10.1128/JCM.01542-07

Casadevall, A., \& Pirofski, L.-a. (1999). Host-pathogen interactions: redefining the basic concepts of virulence and pathogenicity. Infection and Immunity, 67(8), 3703-3713.

Cirl, C., Wieser, A., Yadav, M., Duerr, S., Schubert, S. r., Fischer, H., Stappert, D., Wantia, N., Rodriguez, N. \& Wagner, H. (2008). Subversion of 
Toll-like receptor signaling by a unique family of bacterial Toll/interleukin-1 receptor domain-containing proteins. Nature medicine, 14(4), 399-406 http://doi.org/10.1038/nm1734

Duriez, P., Clermont, O., Bonacorsi, S. p., Bingen, E., Chaventre, A., Elion, J., Picard, B. \& Denamur, E. (2001). Commensal Escherichia coli isolates are phylogenetically distributed among geographically distinct human populations. Microbiology, 147(6), 1671-1676. http://doi.org/10.1099/00221287-147-6-1671

Elmanama, A. A., Al Laham, N. A. \& Tayh, G. A. (2013). Antimicrobia susceptibility of bacterial isolates from burn units in Gaza. Burns, 39(8), 1612 1618. http://doi.org/10.1016/j.burns.2013.04.011

Erjavec, M. S., Jesenko, B., Petkovsek, Z. \& Zgur-Bertok, D. (2010) Prevalence and associations of tcpC, a gene encoding a Toll/interleukin-1 receptor domain-containing protein, among Escherichia coli urinary tract infection, skin and soft tissue infection, and commensal isolates. Journal of clinical microbiology, 48(3), 966-968. http://doi.org/10.1128/JCM.01267-10 Girardini, L. K., Siqueira, F. M., Krewer, C. C., Krewer, C. C., Costa, M. M. d. \& Vargas, A. C. d. (2012). Phylogenetic and pathotype analysis of Escherichia coli swine isolates from Southern Brazil. Pesquisa Veterinaria Brasileira, 32(5), 374-378. http://doi.org/10.1590/S0100-736X2012000500002

Herzer, P. J., Inouye, S., Inouye, M. \& Whittam, T. S. (1990). Phylogenetic distribution of branched RNA-linked multicopy single-stranded DNA among natural isolates of Escherichia coli. Journal of bacteriology, 172(11), 6175-6181. http://doi.org/10.1128/jb.172.11.6175-6181.1990

Johnson, J. R., \& Stell, A. L. (2000). Extended virulence genotypes of Escherichia coli strains from patients with urosepsis in relation to phylogeny and host compromise. Journal of Infectious Diseases, 181(1), 261-272. http://doi.org/10.1086/315217

Johnson, J. R., \& Russo, T. A. (2002). Uropathogenic Escherichia coli as agents of diverse nonâ€"urinary tract extraintestinal infections. Journal of Infectious Diseases, 186(6), 859-864. http://doi.org/10.1086/342490

Johnson, J. R., Kuskowski, M. A., O'Bryan, T. T., Colodner, R. \& Raz, R. (2005). Virulence genotype and phylogenetic origin in relation to antibiotic resistance profile among Escherichia coli urine sample isolates from Israel women with acute uncomplicated cystitis. Antimicrobial agents and chemotherapy, 49(1), 26-31. http://doi.org/10.1128/AAC.49.1.26-31.2005

Jouini, A., Ben Slama, K., Vinue, L., Ruiz, E., Saenz, Y., Somalo, S., Klibi, N., Zarazaga, M., Ben Moussa, M. \& Boudabous, A. (2010). Detection of unrelated Escherichia coli strains harboring genes of CTX-M-15, OXA-1, and AAC (6')-Ib-cr enzymes in a Tunisian hospital and characterization of their integrons and virulence factors. Journal of Chemotherapy, 22(5), 318-323. http://doi.org/10.1179/joc.2010.22.5.318

Kaur, J., Chopra, S. \& Sheevani, G. M. (2013). Modified double disc synergy test to detect ESBL production in urinary isolates of Escherichia coli and Klebsiella pneumoniae. Journal of clinical and diagnostic research: JCDR, 7(2), 229. http://doi.org/10.7860/JCDR/2013/4619.2734

Koga, V. L., Tomazetto, G., Cyoia, P. S., Neves, M. S., Vidotto, M. C., Nakazato, G. \& Kobayashi, R. K. T. (2014). Molecular screening of virulence genes in extraintestinal pathogenic Escherichia coli isolated from human blood culture in Brazil. BioMed research international, 2014 http://doi.org/10.1155/2014/465054

Kuhnert, P., Boerlin, P. \& Frey, J. (2000). Target genes for virulence assessment of Escherichia coli isolates from water, food and the environment. FEMS microbiology reviews, 24(1), 107-117. http://doi.org/10.1111/j.15746976.2000.tb00535.x

Lee, C.-R., Cho, I. H., Jeong, B. C. \& Lee, S. H. (2013). Strategies to minimize antibiotic resistance. International journal of environmental research and public health, 10(9), 4274-4305.

Lillo, J., Pai, K., Balode, A., Makarova, M., Huik, K., KÃ $\mu$ ljalg, S., Ivanova, M., Kaftyreva, L., Miciuleviciene, J. \& Naaber, P. (2014). Differences in extended-spectrum beta-lactamase producing Escherichia coli virulence facto genes in the Baltic Sea region. BioMed research international, 2014. http://doi.org/10.1155/2014/427254

Manges, A. (2016). Escherichia coli and urinary tract infections: the role of poultry-meat. Clinical Microbiology and Infection, 22(2), 122-129. http://doi.org/10.1016/i.cmi.2015.11.010

Micenkova, L., Staudova, B., Bosak, J., Mikalova, L., Littnerova, S., Vrba, M., Sevcikova, A., Woznicova, V. \& Smajs, D. (2014). Bacteriocin-encoding genes and ExPEC virulence determinants are associated in human fecal Escherichia coli strains. BMC microbiology, 14(1), 1 http://doi.org/10.1186/1471-2180-14-109

Nagarjuna, D., Dhanda, R. S., Gaind, R. \& Yadav, M. (2015a). tcpC as a prospective new virulence marker in blood Escherichia coli isolates from sepsis patients admitted to the intensive care unit. New microbes and new infections, 7 , 28-30. http://doi.org/10.1016/j.nmni.2015.05.002

Nagarjuna, D., Mittal, G., Dhanda, R. S., Verma, P. K., Gaind, R. \& Yadav, M. (2015b). Faecal Escherichia coli isolates show potential to cause endogenous infection in patients admitted to the ICU in a tertiary care hospital. New microbes and new infections, 7, 57-66. http://doi.org/10.1016/i.nmni.2015.05.006

Östblom, A., Adlerberth, I., Wold, A. E. \& Nowrouzian, F. L. (2011) Pathogenicity island markers, virulence determinants malX and usp, and the capacity of Escherichia coli to persist in infants' commensal microbiotas. Applied $\begin{array}{llll}\text { and } & \text { 2303-2308 }\end{array}$ http://doi.org/10.1128/aem.02405-10

Paterson, D. L., \& Bonomo, R. A. (2005). Extended-spectrum $\beta$-lactamases: a clinical update. Clinical microbiology reviews, 18(4), 657-686. http://doi.org/10.1128/CMR.18.4.657-686.2005

Pitout, J. D. D. (2010). Infections with extended-spectrum $\beta$-lactamaseproducing Enterobacteriaceae. Drugs, 70(3), 313-333. http://doi.org/10.2165/11533040-000000000-00000

Pitout, J. D. D., Laupland, K. B., Church, D. L., Menard, M. L. \& Johnson, J. R. (2005). Virulence factors of Escherichia coli isolates that produce CTX-Mtype extended-spectrum $\beta$-lactamases. Antimicrobial agents and chemotherapy, 49(11), 4667-4670. http://doi.org/10.1128/AAC.49.11.4667-4670.2005

Ruiz, J., Simon, K., Horcajada, J. P., Velasco, M., Barranco, M., Roig, G., Moreno-Martanez, A., Martanez, J. A., de Anta, T. J. \& Mensa, J. (2002). Differences in virulence factors among clinical isolates of Escherichia coli causing cystitis and pyelonephritis in women and prostatitis in men. Journal of clinical microbiology, 40(12), 4445-4449. http://doi.org/10.1128/jcm.40.12.44454449.2002

Salcedo, S., Marchesini, M. I., Degos, C., Terwagne, M., Von Bargen, K. Lepidi, H., Herrmann, C. K., Santos Lacerda, T. L., Imbert, P. \& Pierre, P. (2013). BtpB, a novel Brucella TIR-containing effector protein with immune modulatory functions. Frontiers in cellular and infection microbiology, 3, 28.

Schmidt, H., \& Hensel, M. (2004). Pathogenicity islands in bacterial pathogenesis. Clinical microbiology reviews, 17(1), 14-56. http://doi.org/10.1128/cmr.17.1.14-56.2004

Slama, K. B., Sallem, R. B., Jouini, A., Rachid, S., Moussa, L., Saenz, Y., Estepa, V., Somalo, S., Boudabous, A. \& Torres, C. (2011). Diversity of genetic lineages among CTX-M-15 and CTX-M-14 producing Escherichia coli strains in a Tunisian hospital. Current microbiology, 62(6), 1794-1801 http://doi.org/10.1007/s00284-011-9930-4

Smith, J. L., Fratamico, P. M. \& Gunther, N. W. (2007). Extraintestinal pathogenic Escherichia coli. Foodborne pathogens and disease, 4(2), 134-163. http://doi.org/10.1089/fpd.2007.0087

Spear, A. M., Rana, R. R., Jenner, D. C., Flick-Smith, H. C., Oyston, P. C. Simpson, P., Matthews, S. J., Byrne, B. \& Atkins, H. S. (2012). A Toll/interleukin (IL)-1 receptor domain protein from Yersinia pestis interacts with mammalian IL-1/Toll-like receptor pathways but does not play a central role in the virulence of Y. pestis in a mouse model of bubonic plague. Microbiology, 158(6), 1593-1606.

Tahamtan, Y., Hayati, M. \& Namavari, M. M. (2010). Prevalence and distribution of the stx1, stx2 genes in Shiga toxin producing E. coli (STEC) isolates from cattle. Iranian journal of microbiology, 2(1), 9-14

Tarchouna, M., Ferjani, A., Ben-Selma, W. \& Boukadida, J. (2013) Distribution of uropathogenic virulence genes in Escherichia coli isolated from patients with urinary tract infection. International Journal of Infectious Diseases, 17(6), e450-e453. http://doi.org/10.1016/j.ijid.2013.01.025

Tayh, G., Sallem, R. B., Yahia, H. B., Gharsa, H., Klibi, N., Boudabous, A. \& Slama, K. B. (2016a). First report of extended-spectrum $\beta$-lactamases among clinical isolates of Escherichia coli in Gaza Strip, Palestine. Journal of Global Antimicrobial Resistance, 6, 17-21. http://doi.org/10.1016/j.jgar.2016.01.013 Tayh, G. A., Laham, A., Nahed, A., Elmanama, A. A. \& Slama, K. B. (2016b) Occurrence and antimicrobial susceptibility pattern of ESBL among Gramnegative bacteria isolated from burn unit of Al Shifa hospital in Gaza, Palestine. The International Arabic Journal of Antimicrobial Agents, 5(3). http://dx.doi.org/10.3823/775

Wayne, P. (2014). CLSI performance standard of antimicrobial susceptibility testing: twenty-fourth international supplement. CLSI Document M100-S24, Clinical and Laboratory Standard Institute.

Yumuk, Z., Afacan, G., Nicolas-Chanoine, M.-H. 1. n., Sotto, A. \& Lavigne, J.P. (2008). Turkey: a further country concerned by community-acquired Escherichia coli clone O25-ST131 producing CTX-M-15. Journal of antimicrobial chemotherapy, 62(2), 284-288. http://doi.org/10.1093/jac/dkn181 Zhang, L., Foxman, B. \& Marrs, C. (2002). Both urinary and rectal Escherichia coli isolates are dominated by strains of phylogenetic group B2. Journal of clinical microbiology, 40(11), 3951-3955 http://doi.org/10.1128/JCM.40.11.3951-3955.2002

Zhao, R., Shi, J., Shen, Y., Li, Y., Han, Q., Zhang, X., Gu, G. \& Xu, J. (2015). Phylogenetic distribution of virulence genes among ESBL-producing uropathogenic Escherichia coli isolated from long-term hospitalized patients. Journal of clinical and diagnostic research: JCDR, 9(7), DC01 http://doi.org/10.7860/JCDR/2015/13234.6157 